\title{
“THATCHERISM AND ITS IMPACT ON CHURCHILL'S TOP GIRLS AND COULD NINE”
}

\author{
Hameed Abdulameer Hameed Alkhafaji \\ Altoosi University College - hameedh@altoosi.edu.iq
}

\begin{abstract}
:
Thatcherism era regards one of the great political and economic trends which have transformed a new lifestyle of British society to be adopting the individualism instead of the socialism. On another word, it is a transformation from welfare capitalism to privatization. This trend strategy has reflected new criteria inside the society. As a result, Thatcherism has given a new transformation concerning the Feminism and its role in the society. The research will shed light on the new concepts of this type of literature. Thus, the discussion and tackling are directed to the selected plays of the playwright Caryl Churchill's Top Girls and Cloud Nine.

The first chapter will discuss the phenomena of Thatcherism during 1979 until 1990. Then, the rest of chapter will mention the impact of Thatcherism on the second wave of feminism and the biography of Caryl Churchill.

In second chapter, the focusing will be on the Thatcherism and its relationship towards the voice of woman. Also, the character Marlene in Churchill's Top Girls will be the point of discussion in terms of the resembling the image of woman that may stand on the next shore to Marlene. The conclusion will sum up the main finding.
\end{abstract}

Key words:

Thatcherism, Second Feminism, Top Girls, Cloud Nine.

Article Received: 18 October 2020, Revised: 3 November 2020, Accepted: 24 December 2020

\section{CHAPTER ONE}

\section{1. Introduction}

\section{What is Thatcherism}

It is the pollical and economic policies advocated by the former British Conservative Prime Minister Margret Thatcher (Oxford Dictionary, online). The definition refers to the role of pollical and economical procedures taken to generate any lifestyle in the UK.

When Thatcher held the premiership, the characteristics of Thatcherism has been expanded to contain: 1. Margaret Thatcher's personal qualities and values, 2. A conviction politics approach to lead the powers of premiership, 3 . The political and economic strategies followed by Thatcher and her ministerial cabinet, 4. distinctive system of economic policies which have applied in the United Kingdom (Jessop 3).

On term of what mentioned, Thatcher's government has been associated with radical right-wing economic strategies and overt opposition to the concept of welfare capitalism, which had had profound social consequences (Marwick 353). When Thatcher acceded to the power, United Kingdom was facing severe economic instability because of high inflation, restrains and shortage of job opportunities. She put an action plan to tackle the critical situation included social economical strategies concentrating on minimizing the intervention of the state through; encouraging the privatization of major nationalized industrial, educational and healthcare systems, decreasing the power of unions through fulfillment of new instructions by urging individual initiatives and small businesses, reducing direct taxation, reducing public expenditures and promoting a competitive free market society (Vasile 243).

On other wards, it can be said that Thatcher's procedures have succeeded in reducing inflation, at the expense of a noticeable increase in unemployment and resulting severe civil instability (Vasile 243). The individualism was clear in Thatcher's statement when she was saying 
"There is no such thing as society. There are individual men and women and there are families"(Naismith xxxvii). Thatcherism has adopted what called 'Enterprise Culture' which refers to disappear the responsibility of state and the prominence of individualism to be "a sheer competitivity at the social, political and economic levels" (Monforte 29).

Moreover, the enterprise culture adopts that the individual initiative and the freedom would replace the dependency (Marwick 311). The emphasis of Thatcherism on the individualism has created new environments in the Britain. The individuals were concerning on themselves and targeting to get money as much as they can which led to emergence the classism in the society, at the meantime, these environments have resulted vast decrease of job opportunities (Vasile 243). This fact has been captured by Churchill in Top Girls which is going to be reviewed in the research.

The decade of 1980s in the Britain has rapid developments and the competitiveness of labor market have been increased widely. As a result, the term of 'Superwoman', that refers to the excellence of woman in life's aspects whether in public or private, has been emerged. The term has been quoted from the personality of Thatcher, who is the daughter of a grocer and mother of two, but she could build her career and has been transformed into an unique symbol of the capitalist superwoman politician. That was definitely embodied in Marlene, the main personality of Top Girls (Vasile 250).

Despite this possible area for woman to build herself personally, most women have suffered from the image of superwoman because the employment situations at that time were very hard and tired. Therefore, there were very few women as "Top Girls" have good positions but the most have being positioned in the bottom list of hierarchies on terms of payments and opportunities of job promotion (Vasile 250-251).

Continuously, Thatcherism has also affected the wave of feminism and feminism theater as well. As it's been mentioned that the social \&political situations in 1970s were pessimistic due to lack of job opportunities and instability of living standards. That's why the tendency of monetarism and power have been presented.

In the research paper, the concentration will be on the impact of the Thatcherism on the feminism movement and the role of Caryl Churchill in reflecting these transformations via its plays especially Top Girls and Cloud Nine. Churchill's literary contribution regard a trend through which we can comprehended that copious duration.

\section{2. Thatcherism and the Second Movement of Feminism}

During 1970s, there was a new wave of feminism has been generated to meet the desires of women who struggled to get part of their rights which another part have been achieved in the first wave of feminism after World War II until 1960s. The wave has tried to foster the fields of life experience toadopt new relationship based on the social and sexual division of labor (Wandor 13).

For achieving such new transformation, in 1971, over 500 from all over the UK have formulated basic demands including: (1) Equal Pay. (2) Equal Education and Opportunities. (3) 24 hours Nurseries. (4) Free Contraception and Abortion on Demand. The demand were a simple expression of desires for material change to improve the position of women. The demands also made a clear link between women's relationship to (a) material social production, (b) the family, (c) individual sexual choice (Wandor 13).

Through reviewing the demands mentioned, it was obviously that the women have eagerly tended to the individualism and determining their own lifestyle. This means that the distinctive lifestyle and experience of woman within society are determined by her own personality and emotions. But the repercussions of that thinking have obviously appeared and affected negatively on the feminism during Thatcher's government when the individuality has been adopted as norm! How?

The answer of that question related to three reasons: First, the reaction against the women wasn't taking big momentum during 
Thatcherism era. Second, Thatcherism was seeing the women as individuals not part of group of movement. Third, the movement of women at that time was growing increasingly fragmented and difficult to characterized as ridged movement. Therefore, the women movement found itself as powerless individuals rather than as a powerful contingency (Gardner 27,42, 44).

\section{3. Churchill and the Social Commitment}

"Caryl Churchill is arguably the most successful and best known socialist feminist playwright to have emerged from second wave feminism. hello please have been their performed all over the world, from the UK and the United States to Korea and Japan" (Aston and Reinelt 174). She is included several anthologies of contemporary drama and her plays regularly have been shown on student reading lists (174). Within theater studies, The work of Churchill has provided the bases for five books and many numerous articles(174). About Churchill's representation and woman performance, she has stimulated and urged some of the most important feminist thinking about the theater since coming to critical attention in the mid-1970s. She came to prominence concurrently with the development of second wave feminism and Britain. She has reflected historical transformations of the eightiesand nineties in plays which stage the central preoccupations and contradictions of these movements as they have shifted and changed. Her theater practice Similarly mirrors a series of challenges changes in hegemonic producing modes over this period. She began as a solitary writer who only came to consider herself a women writer belatedly (Aston and Reinelt 174).

Churchill has explained what she thought about herself:

For years and years I thought of myself as a writer before I thought of my sound as a woman, but recently I've found that I'd say I was a feminist writer as opposed two other people saying money wars I was. I've found that as I go out more into the world and get into situations which involved one man what I feel is quiet strongly a feminist position and that inevitably comes into what I write (Aston and Reinelt 174).

Strand has also highlighted the role of Churchill:

Recognized from her earliest plays as an important feminist voice, Churchill has become unquestionably one of the Britain's most important playwrights, without ever softening her a message or moderating the strength and passion of her ideas (499).

It is very respectfully that Churchill is working so hard to keep the feminism and its consequences embodied in most of her plays for reflecting both challenges and opportunities. Also, she tried to drew a roadmap for the feminism within the huge dramatic changes in the economic and political strategies on the society especially under Thatcherism (Aston and Reinelt 174-180).

\section{CHAPTER TWO}

2. 1. Thatcherism and the voice of woman in Top Girls and Cloud Nine

Cloud Nine and Top Girls are the most two famous plays, which have been written by Caryl Churchill, and they have a feminist prospective. They were produced between 1979 and 1983 . These plays were produced when Britain was being governed by a very poplar trend called Thatcherism. The two plays have established Churchill as one of the most promising feminist writers. Both plays were highly successful in the US bagging Obie Awards (Britannica online).

Cloud Nine has shed light on sensitive issues like gender, race, and colonialism while Top Girls paid attention for the feminism vision during Thatcher's era. It was so prominent that both plays have shown a contrast between historical and contemporary viewpoints.

\section{1. 1. Top Girls}

Top Girls has focused on the contemporary movement which have changed lifeline of woman. The play has been written in 1982 during the first terms of Margaret Thatcher's premiership of the United Kingdom. Churchill herself has articulated the source of inspiration and background for Top Girls (Vasile 234-255): 
It was also that Mrs. Margret Thatcher had just become prime minister; and also I had been to America for a student production of Vinegar Tom and had been talking to women there who were saying things were going very well: they were getting far more women executives, women vicepresidents and so on. And that was such a different attitude from anything I'd ever met here, where feminism tends to be much more connected with socialism and not so much to do with women succeeding on the sort of capitalist ladder. All of those ideas fed into Top Girls (Truss 8).

Through a simple reading to the Churchill's words, it gives an obvious spark expressing that Thatcherism became that first lady who leads a great western state such Britain. In addition, the feminism tendency became much more contributive and social figure as masculinism does. Therefore, "Caryl Churchill wrote Top Girls to question the extent to which second wave feminists were buying into Thatcher ideologies to the detriment of a variety of real woman" (Aston and Reinelt 14)

The play Top Girls testifies women who have made it in man's world, will accept capitalistic structures and learn to function in them. Churchill has embodied 'Marlene' one of the main Top Girls actors to be an example of contemporary women representing Thatcher's ideologies of politics. Marlene regards the central character of Top Girls (Aston and Reinelt 180)

Marlene (or Thatcher), the leading character of the play, has "made it" to the top. However,

Churchill does not merely illustrate Marlene as a successful woman. Rather, Churchill questions how complicated Marlene's attitudes are and what price she pays for being successful. Churchill wanted the play to represent a complex thought process:

What I was intending to do laws make it first look as though it was celebrating the achievement of woman and then -by showing the main character Marlene being successful in a very competitive destructive way- ask what kind of achievement is that? The idea was that it would start out looking like a feminist play and turn into a socialist one, as well (Betsko and Koenig 82).

Betsko and Koenig have also explained the role of sex and class in Top Girls and they affected the events of main actor Marlene who was thinking about herself ;

Although the women share the same sex, each has her own class and cultural concerns. Marlene, however, refuses to acknowledge the obvious differences among the women. Demonstrating her allegiance to the motto "Anyone can do anything if they've got what it takes" (86), Marlene completely ignores class differences. As she tells Joyce, "I don't believe in class" (86). It is not until the erid of the play that Marlene finally admits her self-centered, selfinterested individualism. When Joyce asks for whom the eighties will be stupendous, Marlene responds "For me. I think I'm going up up up .... I believe in the individual. Look at me." (83-84).

For explaining what Churchill tried to target is the dominance and superiority of masculinism and how is this theme has impact negatively on the role of feminism. As a result, Churchill has tried to get rid of this dominance and reflect the new trend which happened in the Britain during Thatcherism era.

All of the women remain blind to the relationship between their misery and their choice to obey or imitate masculine figures. Churchill subsequently explains this problem through realistic representation of an institution which is part of the contemporary world of work. The employment agency scene, which follows the fantastic presentation of the dinner party, shows how Marlene uses her power to intimidate and narrow further an already limited range of options for the women who come seeking employment. She not only acquires to the male standard for success, "far more balls than Howard" (46), but she also becomes an oppressor in her relations with her female clients. In interviews with her clients, Marlene demonstrates her acceptance of patriarchal, capitalist attitudes toward women employees. In their interaction with each other and with clients Marlene and her co-workers in 
the employment agency demonstrate "the ethic of competition" (Kritzer, 141).

On other hand, Churchill has also presented the Victorianism in the Top Girls to give a comparison between Marlene which represent the woman who look forward to equalize the man and the personality of Isabela who represented the Victorian attitude which can't produce straight and trustful personality.

In the case of Isabella, who is a Victorian traveler, is not different from Betty's when the issue is gaining a certain gender role under the control of a male figure. She internalizes the values imposed upon her by her father to such an extend that she is not aware that she is in a situation of self-denial (Firat 21).

In Act one, Scene 1:

ISABELLA: I tried to do what my father wanted ... I tried to be a clergy man's daughter. Needle work, music, charitable schemes ... I studied the metaphysical poets and hymnology. My father taught me Latin although I was a girl. But really, I was more suited to manual work. Cooking, washing, mending, riding horses. Better than reading books ... My father was the main string of my life and when he died, I was so grieved Churchill 2,3)

Since patriarchy considers women to be men's property, inferior, ignorant, and incompetent, its value system claims that women cannot take their own decisions and need to be led by a male figure (Firat 21).

\section{1. 2. Cloud Nine}

For the first time, when the term of Cloud Nine has been seen, the thinking directly goes to the happiness and exciting. To be on 'Cloud Nine' means "To be extremely happy and excited" (Cambridge dictionary online). It seems that the use of term was to the irony on the play. Because; Cloud Nine explores the Victorian origins of contemporary gender definitions and attitudes toward sex, recent social changes which have come about as a result of great numbers of people rejecting Victorian limitations in their own sexual relationships, and some of the implications of these changes. Cloud Nine thus brings together issues of gender, sexuality, and power which had interested Churchill for many years and which she continued to pursue in later plays, as well (Jina Yi 15).

Cloud Nine has presented different aspects of lifestyles and cultures and the consequences of that on the conduct of individuals and society. Also, the play tried to show the impact and role of Victorian conduct on the norm of life.

Cloud Nine juxtaposes two historical periods to manipulate past and present. The first act is set during the height of the Victorian era, in an African country colonized by the British. The second act takes place one hundred years later, in the 1970s London. The Victorian setting depicts a fixed, patriarchal system in which social conventions supersede the valuing of the individual self, and the sex/gender relationship is entirely based on duty instead of individual desire. The present setting is the complete reversal of the past one. It shows a contemporary freedom and chaos in which all kinds of sexual relationships and gender roles are experimented with, eliminating the traditional sex/gender roles and inventing new flexible human relationships based on desire (Jina Yi 17).

The feminist personality of Betty in Cloud Nine gives clear meaning of Victorian conducts and social directions towards the family and woman in particular. Betty represent a striking example of woman who embodied the obedience and following the manhood in spite of the suffering she receives by her colonialist husband Clive.

Betty regards one of main actors, who has encoded all of the female behaviors intensifies the message, that Betty, without her real and natural self, simply follows all the female behaviors demanded by patriarchal Victorian values and regulations. When the actor playing Betty wears a beautiful dress, his awkward feminine manner can effectively convey the message that Betty is forced to play a Victorian woman. Like the male player who is assigned the role of Betty, Betty has to play the role of Victorian woman, fragile and helpless, who often has hysterics and fainting fits and who should patiently wait for her husband at 
home, despite her depression and boredom. Betty's assigned role in the colonial country is only to miss her husband at home when he is away keeping the savages under control and to maintain a comfortable place of escape from the wicked, cruel world outside the home. She should not be herself. Instead, she should play the assigned role of mother, daughter, and wife (Jian Yi 19-20).

In a quick view, the actors in act one re-appear in a new role within act two. While Act One depended largely on cross-casting, in Act Two, Churchill introduced the time shifting and doublecasting. The characters of the second act try to find their "own selves" and to avoid playing the given roles prescribed by social conventions as in Act One. They seek to escape from the social, political, and sexual entrapment of the Victorian age. This fact is clearly made visible in the actors, who change roles from the first act (Jina Yi 26). This fact has been clarified by Churchill when she mentioned:

The story does not just correspond to an incident from men's life together as it might actually have taken place, but is composed of episodes rearranged so as to allow the story teller's ideas about men's life to find expression. In the same way the characters are not simply portraits of living people, but are rearranged and formed in accordance with ideas (Churchill 278).

Moreover, it could see that In Act One, everybody is narrowly confined to the artificial role pushed onto him or her by Victorian conventions, but in Act Two, they are confronted with their limitless possibilities: all become both more certain about their desires and confused about their chosen roles. Churchill's suggestion for the director's options reflects a contemporary assumption that we live in a realm in which multiple options are available (Jina Yi 28).

When reviewing Cloud Nine, Caryl Churchill planned to switch actors to show both gender and race in the actual performance of her play. In effecting a distance between assumed persona and real self, performance involves pretense or dissimulation and these qualities relate acting to the character's social change. Like actors whose true sex or race is masked by cross-casting, the characters in the first act conceal and suppress their desires under their social masks (Jina Yi 20).

All characters of Cloud Nine reveal problems in their sexual relationships. Even though characters in the second act have many options and more freedom, with the new freedom comes confusion. Lin is attracted to Vic. Gerry rejects Edward's desire for exclusive commitment, declares a 'divorce' from him, and later describes, in a monologue, the type of risky and anonymous erotic encounter he finds most exciting. Betty experiences great anxiety about her new independence. Martin pressures Vic to make a decision on a job offer in another city and complains that she does not respond sexually. While the characters attempt to find their own selves through this new freedom of selfexpression, they are not clear about the direction in which they move; moreover, they do not clearly understand people of the opposite sex and class. Betty and Victoria (women) and Edward, Gerry, and Lin (homosexuals) are simply enjoying their newly acquiredfreedoms by unleashing their sexual desires through various sexual experiments. However, they do that without any clear idea of why they are doing so and without any specific goals (Jina Yi 30)

In Act two, the scenes focused on the changes in the structure of the power and authority as these impact on sex and relationship. It is shown immediately juxtaposing a strong contemporary image against vivid images of the past.

Churchill, in a reflection upon the values within her play, states in the introduction that "all the characters in this act change a little for the better" (246). The types of change that might definitively alter power relations. The play can show how Betty's husband, Clive, has picturized Betty personality at the fist act when Cloud Nine opens with Clive's presentation of his family members to the audience. The opening presentation introduces the key motif of the first 
act: the repression of the female self in the Victorian age. Clive, a nineteenth-century colonial administrator, introduces himself and his wife, Betty:

Clive: I am a father to the natives here,

And father to my family so dear.

My wife all dreamt a wife should be,

And everything she is she owes to me(Churchill 251).

In the play, Clive defines his wife as a woman who lacks her own self, a woman whom he creates according to his own male values, a woman who belongs entirely to him. Then, at the second act, Betty seems more liberal from the Victorian living style when she has attracted to other man and she broke the rules of marriage, then she became divorced. These conditions give a clear indicator about how the authoritarian rules of Victorianism became not being willing nor followed as it was before. Also, the complicated relationship between Clive and his son, Edward, refers to Victorian treatment. Clive has shown a severe Victorianism through his roughly dealing with his son, Edward, who is homosexual and tried to find his personality, but he failed. Instead, he found himself by playing the role of mother and taking care of children. The transformation of Edward refers to the failure of Clive's victorian restriction towards his family. As a result, Edward became an opposite copy of person that Clive was looking forward to see.

"CLIVE: You should always respect and love me, Edward, not for myself, I may not deserve it, but as I respected and loved my own father, because he was my father. Through our father, we love our queen and our God, Edward. Do you understand? It is something men understand." (276)

\section{CONCLUSION}

The research papers have highlighted the era of Thatcherism with details to understand how the impact of Prime Minister Margret Thatcher on the Second Feminism Movement, politics, and economy have changed life of individuals. The impacts of Thatcherism are also clear in the literature in which many literary works are devoted to capture the image of woman at that period. Caryl Churchill was one of pioneering figure who adopted that image of woman in her plays Cloud Nine and Top Girls. Churchill was trying to present, express and discuss this image through her character Marlene who comes to be an ideal representation of that image of woman. Marlene embodied all the features of the iron woman image via her behavior and speeches. On the other hand, Betty stands at the backstage of this image. Betty in fact is still imprisoned in the old image of woman. She has tried hard to reestablish herself, but her efforts went in vain.

Churchill through her literary works was trying to reflect the image in question to the British woman particularly and all the woman of the world generally. Her writings were devoted to bring that image of woman to the sunshine.

\section{WORKS CITED}

[1] Aston, Elaine. Caryl Churchill. 2nd ed. United Kingdom: Northcote House Publishers Ltd, 2001.

[2] Aston, Elaine and Reinelt, Janelle. 1st ed. The Cambridge Companion to Modern British Women

[3] Playwrights. Cambridge University Press, 2000.

[4] Betsko, Kathleen and Rachel Koenig. Interviews with Contemporary Women Playwrights. New

[5] York: Beech Tree, 1987. pp. 72-114.

[6] Cambridge Dictionary Online:https://dictionary.cambridge.org/di ctionary/english/be-on-cloud-nine

[7] Churchill, Caryl. Top Girls. Methuen London Ltd, 1982.

[8] Churchill, Caryl. Cloud Nine. Methuen London Ltd, 1979.

[9] Encyclopedia Britannica, Caryl Churchill Biography. 2019.

[10] https://www.britannica.com/biography/Car yl-Churchill

[11] Firat, Serap, Caryl Churchill And Gender Roles: Owners, Cloud Nine, And Top Girls. Master 
[12] thesis, Middle East Technical University. 2005.

[13] Jessop, Bob. "Margaret Thatcher and Thatcherism: Dead but Not Buried." British Politics 10.1

[14] (2015): pp. 16-30. Crossref. Web.

[15] Kritzer, Amelia Howe. The Plays of Caryl Churchill: Theatre of Empowerment. London: Macmillan, 1991.

[16] Marwick, Arthur, British Society since 1945, London, Penguin, 1990 (1982).

[17] Monforte, Enric, Gender, Politics, Subjectivity: Reading Caryl Churchill, Barcelona, PPU. 2001.

[18] Naismith, Bill. "Commentary". Caryl Churchill. Top Girls, London: Methuen, 1991 (1982), xxi-liii.

[19] Strand, Ginger. "Caryl Churchill." Encyclopedia of World Literature in the 2nd Century. Voll. Rev 3rd ed. USA: St. James Press-Gale, 1999.

[20] Tuss, Lynne. "A Fair Cop." Plays and Players. Jan. 1984: 8-10.

[21] Vasile, Carmen Georgiana. The Female Voices in Caryl Churchill's Top Girls: Sisters or Foes?

[22] ISSN 2013-9686. Anagnorisis Press, 2010 pp. 234-259.

[23] Wandor, Michelene. Carry On, Understudies: Theatre and Sexual Politics. New York, Routledge and Kegan Paul, 1986 (1981).

[24] Yi, Jina, "Envisioning Identity: Theatrical and Political Innovations in Caryl Churchill's Plays." Master's Thesis, University of Tennessee, 2004. 